\title{
ETOS KERJA DALAM BUDAYA ORGANISASI DI KANTOR KEMENTERIAN AGAMA KABUPATEN GRESIK
}

\author{
Indah Nur Faizah, Linda Lisma Lestari, Syahrul Hidayat, Ali Mustofa \\ UIN Sunan Ampel, Surabaya - Indonesia | nurfaizahindah38@gmail.com
}

\begin{abstract}
Abstrak: One of the successes of an organization is the realization of the goals, objectives, vision and mission of the organization in accordance with the organization's strategic planning. Good performance will be seen in quality results. An appropriate organizational culture and good work ethic will greatly help in improving the quality of performance for the better. This research was conducted on employees at Islamic Religious Education (PAIS) with the aim of knowing the drivers of employee work ethics and organizational culture without the presence of permanent leaders. The method used in this research is descriptive qualitative method. The result of this research is that although the PAIS section does not have permanent leadership, the service can run well without any obstacles. Work ethic and organizational culture are one of the drivers in improving the quality of employee performance. The work ethic in the Islamic Religious Education section of the Ministry of Religion of Gresik Regency is to work optimally, carry out their duties and responsibilities as workers who are able to contribute and do work wholeheartedly and avoid despicable actions. The factors that influence work ethic at PAIS include the presence of organizational culture. The Islamic Religious Education (PAIS) section is based on five cultural values in the ministry of religion, namely (1) Integrity, (2) Professionalism, (3) Innovation, (4) Responsibility, (5) Exemplary.
\end{abstract}

Keywords: Work Ethic, Organizational Culture

\section{Pemdahuluan}

Kinerja adalah gambaran mengenai tingkat pencapaian pelaksanaan suatu program kegiatan atau kebijakan dalam mewujudkan sasaran, tujuan, visi dan misi organisasi yang dituangkan melalui perencanaan strategis organisasi (Moeheriono, 2012, hal. 95). Kinerja yang rendah akan berdampak negatif seperti 
penurunan sistem kerja yang membuat pekerjaan semakin lamban untuk diselesaikan. Bagi suatu organisasi kinerja merupakan hasil yang dicapai dari kegiatan kerjasama diantara para anggota atau komponen organisasi dalam rangka mewujudkan tujuan organisasi. Kinerja organisasi pada dasarnya merupakan tanggung jawab setiap anggota organisasi. Baik buruknya kinerja pegawai dipengaruhi oleh nilai-nilai budaya dan etos kerja diorganisasi tersebut. Budaya organisasi dalam sebuah perusahaan biasanya dikaitkan dengan nilai, norma, sikap dan etika kerja yang dipegang bersama oleh setiap komponen organisasi. Unsur inilah yang menjadi dasar untuk mengetahui bahwa kemajuan suatu organisasi tidak hanya dari dorongan pemimpinnya akan tetapi juga budaya organisasi yang memunculkan etos kerja baik bagi kinerja pegawai di Seksi Pendidikan Agama Islam Kemenag Gresik. Budaya organisasi diyakini merupakan faktor penentu utama terhadap kesuksesan kinerja organisasi. Jika budaya organisasi berjalan dengan baik, maka akan dapat meningkatkan kinerja karyawan (Gultom, 2014). Menurut Schein (Hendyat Soetopo, 2010, hal. 125) budaya organisasi adalah suatu pola asumsi dasar, diciptakan, diketahui, atau dikembangkan oleh suatu kelompok untuk mengatasi masalah adaptasi eksternal dan integrasi internal, sehingga dianggap perlu diajarkan kepada anggota baru sebagai cara yang benar dalam memandang, berpikir, dan berperasaan mengenai masalah yang dihadapinya.

Salah satu nilai yang terdapat dalam budaya organisasi adalah etika kerja. Menurut Edy Sutrisno (2013, hal. 105) mengatakan bahwa etos kerja adalah norma- norma yang bersifat mengikat dan ditetapkan secara eksplisit serta praktik-praktik yang diterima dan diakui sebagai kebiasaan yang wajar untuk dipertahankan dan ditetapkan dalam kehidupan kekaryaan para anggota suatu organisasi. Peran penting dalam etos kerja dirumuskan kedalam delapan aspek Etos Kerja menurut Sinamo (2005, hal. 20-21) yaitu, kerja adalah rahmat, kerja adalah amanah, kerja adalah panggilan, kerja adalah aktualisasi, kerja adalah ibadah, kerja adalah seni, kerja adalah kehormatan, kerja adalah pelayanan. 
Hal yang menjadi sorotan peneliti dalam penelitian ini adalah tidak adanya pemimpin tetap dalam seksi Pendidikan agama islam (PAIS). Hal ini menjadi suatu keunikan dikarenakan meskipun tidak ada pemimpin yang tetap dalam seksi PAIS akan tetapi layanan dapat berjalan dengan baik dan kinerja pegawai yang maksimal. Hal itu menjadikan peneliti ingin mengetahui etos kerja dalam budaya organisasi di Seksi Pendidikan Agama Islam (PAIS) Di Kemenag Gresik.

Dengan kualitas sumber daya manusia yang baik, maka hal tersebut menjadi nilai lebih bagi perusahan, oleh karena itu sumber daya yang baik diharapakan mampu membuat tenaga kerja dengan etos yg baik dan menjadi budaya yang baik bagi perusahaan. Yang akan mencetak sumber daya manusia yang berkualitas. Tujuan dari penelitian ini adalah untuk mengetahui etos kerja dalam budaya organisasi di Seksi Pendidikan Agama Islam (PAIS) di Wilayah Kantor Kementerian Agama Kabupaten Gresik.

\section{Metodologi}

Menurut Sugiyono definisi metode penelitian adalah cara ilmiah untuk mendapatkan data dengan tujuan dan kegunaan tertentu. Dengan metode penelitian, peneliti bermaksud mengumpulkan data dan mengamati secara seksama mengenai aspek-aspek tertentu yang berakitan erat dengan masalah yang diteliti sehingga akan diperoleh data yang menunjang penyusunan laporan penelitian.

Dalam penelitian ini, peneliti menggunakan metode kualitatif deskriptif dalam menganalisis data karena pendekatan ini dipandang dapat menemukan dan memahami sebuah masalah secara detail atau menyeluruh (Sugiyono). Teknik penentuan informan dalam penelitian ini adalah dengan purposive sampling yakni memilih informan yang dianggap paling paling memahami mengenai permasalahan dalam penelitian. Dalam penelitian ini informan yang tepat yakni pegawai atau staff yang ada di Seksi PAIS.

Analisis data diawali dengan melakukan wawancara mendalam dengan informan. setelah melakukan wawancara, peneliti menarasikan yang sesuai dengan apa yang didapatkan saat 
melakukan wawancara. Selanjutnya, penulis membuat reduksi data dengan cara abstraksi yakni mengambil data yang sesuai dengan konteks penelitian dan mengabaikan data yang tidak diperlukan.

Penelitian kualitatif harus memiliki kredibilitas sehingga dapat dipertanggung jawabkan. Kredibilitas merupakan keberhasilan mencapai maksud mengekplorasikan masalah yang manjemuk atau keterpercayaan terhadap hasil data penelitian.

Upaya untuk menjaga kredibilitas dalam penelitian yakni dengan memperhatikan langkah-langkah sebagai berikut : (1)Perpanjangan pengamatan, Peneliti kembali ke lapangan untuk melakukan pengamatan guna mengetahui kebenaran data yang diperoleh maupun menemukan data baru. (2)Meningkatkan ketekunan, Melakukan pengamatan secara lebih cermat. Dengan meningkatkan ketekunan, peneliti melakukan pengecekan kembali apakah data yang ditemukan sudah benar atau salah. (3)Triangulasi, Pengecekan data sebagai sumber dengan berbagai cara dan berbagai waktu. (4)Analisis kasus negative, Peneliti mencari data yang berbeda dengan data yang ditemukan. Apabila tidak ditemukan data yang berbeda maka data yang ditemukan sudah bisa dipercaya. (5)Menggunakan bahan referensi. Bahan referensi dimaksudkan untuk pendukung data yang ditemukan, sebagai contoh data hasil wawancara perlu didukung adanya rekaman wawancara. (6)Menggunakan member check, Membuat kesepakatan dengan informan penelitian bahwa data yang telah diterima sudah sesuai dengan hasil wawancara. Apabila data sudah benar maka data sudah dianggap valid. Peneliti juga perlu melakukan diskusi dengan pemberi data supaya penafsiran akan data yang diperoleh dapat disepakati.

\section{Hasil dan Pembahasan}

\section{Etos Kerja}

Etos berasal dari Bahasa Yunani (ethos) yang berarti sikap, kperibadian, watak, karakter, serta keyakinan atas sesuatu. Etos dibentuk oleh berbagai kebiasaan, pengaruh budaya, serta system nilai yang diyakininya. Etos kerja adalah semangat kerja yang menjadi ciri khas dan keyakinan seseorang atau suatu kelompok. 
Menurut Sinamo etos kerja adalah seperangkat perilaku kerja positif yang berakar pada kesadarab yang kental, keyakinan yang fundamental, disertai komitmen yang total pada paradigm kerja yang integral.

Setiap organisasi yang selalu ingin maju, akan melibatkan anggota untuk meningkatkan mutu kinerjanya, diantaranya setiap organisasi harus memiliki etos kerja. Tasmara dalam Thohah (2007:257) mengatakan bahwasannya etos kerja merupakan totalitas kepribadian dirinya serta caranya mengekspresikan, memandang, meyakini dan memberikan makna terhadap sesuatu yang mendorong dirinya untuk bertindak dan meraih hasil yang optimal (high performance) sehingga pola hubungan antara manusia dengan dirinya dan antara manusia dengan makhluk lainnya dapat terjalin dengan baik.

Dari beberapa pengertian diatas, dapat ditarik kesimpulan bahwasannya etos kerja menggambarkan suatu sikap. Etos kerja mengandung makna sebagai aspek evaluatif yang dimiliki oleh individu atau kelompok dalam memberi penilaian terhadap kerja. Hal-hal penting yang berhubungan dengan etos kerja yakni : (1)Orientasi ke masa depan, yakni segala sesuatu direncanakan dengan baik, mulai dari waktu, kondisi untuk ke depan supaya lebih baik dari yang kemarin.(2)Menghargai waktu dengan adanya disiplin waktu merupakan hal yang sangat penting guna dan efisien dan efektivitas bekerja. (3)Tanggung jawab, yaitu dengan cara memberikan asumsi bahwa pekerjaan yang dilakukan sesuatu yang harus dikerjakan dengan ketekunan dan kesungguhan. (4)Hemat dan sederhana, yaitu dengan cara tidak boros sehingga pengeluaran itu bermanfaat untuk kedepannya. (5)Persaingan sehat, yaitu berpacu dengan menambah kreativitas dan tidak mudah patah semangat.

Adapun indikator-indikator yang dapat menjadi acuan tinggi rendahnya etos kerja dijabarkan oleh Gama (1996:224) yang mendefinisikan etos kerja sebagai sejumlah nilai- nilai budaya yang diungkapkan oleh sikap dan tindakan seseorang atau sekelompok orang, yang didalamnya terkandung nilai-nilai moral dan pandangan tentang kerja. Etos kerja itu adalah sesuatu yang berada 
di belakang derajat dan kualitas kerja seperti kerja keras, tepat waktu, jujur dan ulet dalam bekerja, berorientasi kepada prestasi, kreatif dan berorientasi pada perubahan. Setiap karyawan harus memelihara kesopanan, etika dalam bersikap dan tingkah laku di dalam maupun di luar Kantor.

Etos kerja dipengaruhi oleh beberapa factor, diantaranya yaitu (Anoraga, 2011:52) : (1)Agama, pada dasarnya agama merupakan suatu system nilai yang akan mempengaruhi atau menentukan pola hidup para penganutnya. Cara berpikir, bersikap dan bertindak seseorang diwarnai oleh ajaran agama yang dianut jika seseorang sungguh-sungguh dalam kehidupan. (2)Budaya. Sikap mental tekad, disiplin dan semangat kerja masyarakat juga disebut sebagai etos kerja budaya dan secara operasional etos budaya ini juga disebut sebagai etos kerja. (3)Sosial politik, tinggi rendahnya etos kerja juga dapat diperngaruhi oleh ada tidaknya struktur politik yang mendorong masyarakat untuk bekerja keras dan dapat menikmati hasil kerja keras. (4)Kondisi Lingkungan atau Geografis. Lingkungan alam yang mendukung dapat mempengaruhi manusia yang berada di dalamnya melakukan usaha untuk dapat mengelola dan mengambil manfaat dan bahkan dapat mengundang pendatang untuk turut mencari penghidupan di lingkungan tersbut. (5)Pendidikan. . Peningkatan sumber daya manusia akan membuat seseorang mempunyai etos kerja. (6) Struktur ekonomi. Etos kerja suatu masyarakat juga dipengaruhi oleh ada atau tidaknya struktur ekonomi, yang mampu memberikan insentif bagi anggota masyarakat untuk bekerja keras dan menikmati hasil kerja kerasnya. (7) Motivasi Intrinsik Individu. Sesorang yang memiliki etos kerja tinggi ialah individu yang bermotivasi tinggi. Etos kerja merupakan suatu pandangan dan sikap yang didasari oleh nilainilai yang diyakini.

\section{Budaya Organisasi}

Manusia dipengaruhi oleh kebudayaan setempat atau Lingkungannya. Misalnya, seseorang yang dibesarkan dalam lingkungan Pesanteren akan di didik nilai-nilai, kepercayaan, dan perilaku-perilaku yang diharapkan sesuai dengan agama, yang umum terjadi pada keluarga dalam kelas tersebut. Kebudayaan 
merupakan cermin cara berpikir seorang individu maupun sebuah golongan dan cara bekerja manusia.

Ketika memahami sebuah budaya organisasi pasti tidak lepas dari konsep dasar budaya. Menurut Edward, menjelaskan kebudayaan adalah sebagai keseluruhan yang kompleks, yang di dalamnya terkandung pengetahuan, kepercayaan, kesenian, moral, hukum, adat istiadat, dan kemampuan-kemampuan lain yang didapat seseorang sebagai anggota masyarakat.

Adapun penjelasan lain tentang definisi budaya, Pertama bahwa budaya adalah sebuah persepsi, ia bukanlah sesuatu yang dapat dilihat secara mata telanjang namun dapat kita pahami melalui apa yang mereka alami dalam sebuah organisasi atau dalam kehidupannya dilingkungan sekitar seperti perilaku para anggota atau cara berpikir, merasa, menanggapi dan menuntut para anggota organisasi dalam mengambil keputusan ataupun dalam kegiatan lainnya. Kedua, Budaya organisasi bersifat deskriptif, yaitu berhubungan dengan sudut pandang masing-masing dalam mengartikan budaya tersebut berdasarkan nilai, norma, aturan, falsafah, dan kepercayaan yang diyakini oleh sebuah organisasi yang tercermin dalam pola pikir dan perilaku para anggota organisasi, terlepas dari setuju atau tidak mereka. Dan ketiga aspek penerimaan ( penganutan ) meskipun dalam sebuah organisasi itu beraneka ragam latar belakang namun mereka bisa satu tujuan dalam mengutarakan budaya organisasi.

Dalam organisasi terdapat budaya organisasi, budaya organisasi mengacu pada sebuah sistem makna bersama yang dianut oleh para anggota yang membedakan organisasi tersebut dengan organisasi lainnya. Menurut Robbins yang dikutip oleh Siswanto dan Sucipto, budaya organisasi ialah nilai-nilai yang didukung oleh organisasi atau falsafah yang menuntun pada kebijaksanaan organisasi terhdap pegawai dan pelanggan, ataupun cara pekerjaan dilakukan di tempat kerja, atau asumsi dan kepercayaan dasar yang terdapat diantara anggota organisasi.

Budaya organisasi tidak dapat dinilai oleh mata, tetapi bisa dirasakan melalui perilaku para anggota ataupun cara berpikir, kepekaan, menanggapi dan menuntut para anggota organisasi 
dalam membuat keputusan atau dalam kegiatan yang lain. Selanjutnya, Menurut Schein (1985) budaya organisasi adalah pola asumsi dasar yang ditemukan atau dikembangkan oleh suatu kelompok orang ketika merekan belajar untuk menyelesaikan masalah-masalah, menyesuaikan diri dengan lingkungan eksternal, dan berintegrasi dengan lingkungan internal. Budaya organisasi adalah satu wujud anggapan yang dimiliki, diterima secara implisit oleh kelompok dan menentukan bagaimana kelompok tersebut rasakan, pikirkan, dan bereaksi terhadap lingkungannya yang beraneka ragam (Kreitner dan Kinicki, 2005).

Berpijak dari beberapa pendapat diatas, dapat disimpulkan bahwasannya budaya organisasi dapat diartikan sebagai nilai, norma, aturan, falsafah, dan kepercayaan yang diyakini oleh sebuah organisasi yang tercermin dalam pola pikir dan perilaku para anggota organisasi. Adapun karakteristik dari budaya organisasi menurut Robbins yang terbagi menjadi tujuh karakteristik utama, diantaranya : (1)Inovasi dan pengambilan risiko, yakni sejauh mana para karyawan didorong untuk inovatif fan mengambil risiko. (2)Perhatian ke rincian, yakni sejauh mana para karyawan diharapkan memperlihatkan presisi (kecermatan) analisis dan perhatian kerincian. (3) orientasi hasil, yaitu sejauh mana manajemen memusatkan pada hasil bukannya pada teknik dan proses yang digunakan untuk mencapai hasil itu, (4)Orientasi orang, yaitu sejauh mana keputusan manajemen memperhitungkan efek hasil-hasil pada orang dalam organisasi tersebut. (5)Orientasi tim, yaitu sejauh mana kegiatan kerja diorganisasikan sekitar timtim, bukannya individu. (6)Keagresifan, yaitu sejauh mana orang dalam organisasi tersebut agresif dan kompetitif bukan santaisantai. (7)Kemantapan, yaitu sejauh mana kegiatan organisasi menekankan dipertahankannya status quo sebagai kontras dari pertumbuhan. Menurut Luthans dalam Sopiah menyebutkan sejumlah karakteristik penting dari budaya organisasi, meliputi: (1)Aturan-aturan perilaku, yakni bahasa, termonologi dan ritual yang biasa dipergunakan oleh anggota organisasi. (2)Norma adalah standard perilaku yang meliputi petunjuk bagaimana melakukan sesuatu.(3)Nilai-nilai dominan yakni niali utama yang diharapkan 
ari organisasi untuk dikerjakan oleh para anggota, misalnya tingginya kualitas produk, rendahnya tingkat absensi, dan lainlain.(4)Filosofi terkait kebijakan yang dipercaya organisasi tentang hal-hal yang disukai para karyawan dan pelanggannya. (5)Peraturan-peraturan yang tegas dari organisasi.(6)Iklim organisasi yakni keseluruhan perasaan yang meliputi hal-hal fisik, bagaimana para anggota berintraksi dan bagaimana para anggota mengendalikan diri dalam berelasi dengan pelanggan.

Budaya organisasi merupakan nilai dan keyakinan bersama yang mendasari identitas perusahaan. Ada beberapa fungsi budaya organisasi, diantaranya; (1)Memberikan identitas organisasi kepada karyawannya, sebagai perusahaan yang inovati yang memburu pengembangan produk.(2)Memudahkan komitmen koletif, sebuah perusahaan dimana karyawannya bangga menjadi bagian darinya atau cenderung tetap bekerja dalam waktu yang lama.(3)Mempromosikan stabilitas sytem sosial, mencerminkan taraf dimana lingkungan kerja dirasa positif dan mendukung, konflik dan perubaahan diatur secara efektif.(4)Membentuk perilaku dengan membantu manajer merasakan keberadaannya, dimana membantu karyawan atau pegawi memahami mengapa organisasi melakukan apa yang seharusnya dilakukan dan bagaimana perusahaan bisa menapai tujuan jangka panjang.

Jika budaya terbentuk dari norma-norma moral, sosial dan perilaku dari sebuah organisasi yang didasarkan pada keyakinan, kesopanan, dan prioritas anggota- anggotanya, maka pemimpin dapat diartikan sebagai anggota dan banyak mempengaruhi perilaku-perilaku dengan contoh ketulusan anggota organisasi itu sendiri. Di dalam model manajemen apapun, para pemimpin selalu bertanggungjawab atas keteladanannya (Robbins, 2003).

Kuat lemahnya budaya sebuah organisasi dapat diperhatikan dengan melihat tiga hal yakni : (1)Arah, apakah nilai-nilai yang hidup searah atau selaras atau mendukung tujuan organisasi. (2)Penyebaran, apakah nilai-nilai budaya tersebut dihayati dan dimiliki oleh semua anggota dalam organisasi atau hanya sekelompok kecil manajer tingkat atas. (3)Intensitas, apakah pengaruh budaya tertentu memberi tekanan (biasanya melalui 
tekanan kelompok) yang kuat pada anggota organisasi hingga ditaati atau tidak. Selain itu, budaya organisasi yang kuat dapat dilihat dari sejauhmana nilai-nilai inti organisasi dapat mendominasi dan dijadikan sebagai pedoman perilaku bagi seluruh anggota organisasi. Supaya budaya organisasi dapat terus dijadikan sebagai pedoman maka budaya organisasi harus tetap memiliki fungsi dan manfaat optimal bagi organisasi, dan untuk itu kedinamisan budaya organisasi menjadi faktor yang perlu dipertimbangkan.

Etos Kerja dalam Budaya Organisasi di Seksi Pendidikan Agama Islam Wilayah Kantor Kementerian Agama Kabupaten Gresik

Etos kerja pegawai yang ada pada Seksi Pendidikan Agama Islam Kemenag Kabupaten Gresik tergolong cukup baik. Hal ini dikarenakan pada bagian ini beban tugas hanya dikerjakan oleh 2 (dua) pegawai dan juga selama beberapa bulan ini dipimpin oleh Pelaksana Tugas (PLT) tetapi semuanya bisa terselesaikan sesuai dengan target waktu yang sudah ditentukan. Pada dasarnya meskipun pada seksi ini tidak memiliki pimpinan tetap, namun sudah ada pelaksana tugas yang menggantikan jabatan pimpinan pada bagian ini yang sifatnya hanya sementara, sehingga dalam melaksanakan tugas tidak dapat melaksanakan semua portofolio yang diberikan pada jabatannya itu.

Dalam perencanaan etos kerja pegawai Pendidikan Agama Islam (PAIS) menghendaki bekerja secara maksimal, melaksanakan tugas dan tanggung jawabnya sebagai pekerja yang mampu memberikan kontribusi terhadap instansi. Selain itu, pelaksanaan etos kerja di Seksi PAIS ditandai dengan melakukan pekerjaan dengan sepenuh hati dan menjauhi tindakan tercela, misalnya mangkir kerja, tidak disiplin, tidak memenuhi tanggung jawab sebagai tenaga kerja yang memberikan jasa berupa layanan, Mampu menahan diri untuk tidak melakukan perrbuatan yang dapat menimbulkan hilangnya kepercayaan masyarakat khususnya guru agama islam.

Faktor yang mempengaruhi etos kerja di PAIS diantaranya ialah adanya budaya organisasi. Budaya organisasi merupakan nilai, norma, aturan, falsafah, dan kepercayaan yang diyakini oleh sebuah 
organisasi yang tercermin dalam pola pikir dan perilaku para anggota organisasi. Meskipun tidak dapat dinilai oleh mata, tetapi budaya organisasi bisa dirasakan melalui perilaku para anggota ataupun cara berpikir, kepekaan, menanggapi dan menuntut para anggota organisasi dalam membuat keputusan atau dalam kegiatan yang lain. Dalam hal ini, Pegawai yang ada pada Seksi PAIS menerapkan budaya organisasi diantaranya membagi pekerjaan sesuai dengan tugas dan fungsi masing- masing supaya memudahkan pekerjaan cepat selesai dengan maksimal. Tugas lainnya yang dijalankan pada seksi ini ialah mengelola EMIS, Sistem informasi dan administrasi guru agama, daftar isian pengelolaan anggaran (DIPA), serta Manajemen Peningkatan Mutu Guru. Karena dalam satu ruangan hanya terdapat dua orang maka tiap pegawai memegang lebih dari satu tugas, misalnya saja Bapak Abdullah yang merupakan salah satu pegawai di Seksi PAIS mengendalikan EMIS dan Manajemen peningkatan mutu guru. Hal ini termasuk karakteristik pegawai yang memiliki etos kerja dalam budaya organisasi yang mana berani mengambil resiko, agresif dan orientasi terhadap tim.

Penyelesaian pekerjaaan di PAIS dengan etos kerja yang tinggi tentu akan mempengaruhi kualitas layanan yang diberikan kepada masyarakat khususnya guru agama di wilayah Kabupaten Gresik. Oleh karenanya penting sekali kontribusi dan komitmen tinggi dari pegawai yang ada pada seksi ini. Bahkan pada masa pandemi COVID-19 ini pelayanan terhadap penjaminan mutu guru agama islam di Kabupaten Gresik tetap dilaksanakan meskipun dilakukan secara virtual atau dalam jaringan (Daring). Layanan yang diberikan untuk meningkatkan mutu guru agama islam ialah dengan mengadakan workshop, seminar untuk kelompok kerja guru (KKG), dan musyawarah guru mata pelajaran (MGMP).

Pekerjaan yang ada pada seksi ini dapat berlangsung sesuai dengan tujuan meskipun dipimpin oleh pelaksana tugas dikarenakan beberapa faktor pendukung lainnya, yakni pembagian tugas yang jelas di Seksi Pendidikan Agama Islam, pegawai bekerja dengan ikhlas dan sepenuh hati, memperhatikan dan mengutamakan kualitas layanan, terus belajar serta menjalin 
komunikasi yang baik antar pihak internal maupun eksternal. Pelaksanaan etos kerja dapat diwujudkan melalui suatu jalinan kerjasama antara pegawai dan pegawai serta antara pegawai dan pimpinan. Peran pelaksana tugas atau pemimpin sementara di seksi ini ialah membimbing dan memberikan arahan apabila pegawai mengalami kendala atau permasalahan terkait pekerjaan yang ada. Dengan begitu semua akan terarah sesuai dengan budaya organisasi yang ada di seksi ini yakni mengutamakan etos kerja pegawai.

Kuat lemahnya budaya organisasi dapat dilihat dari sejauhmana nilai-nilai inti organisasi dapat mendominasi dan dijadikan sebagai pedoman perilaku bagi seluruh anggota organisasi. Pada seksi pendidikan agama islam perilaku atau sikap yang harus diperhatikan supaya pegawai fokus pada peningkatan layanan ialah berpijak pada lima nilai budaya kerja yang ada di kementerian agama, yaitu (1)Integritas, keselarasan antara hati, pikiranm, perkataan dan perbuatan yang baik dan benar. (2)Profesionalitas, Bekerja secara disiplin, kompeten dan tepat waktu dengan hasil terbaik. (3)Inovasi, menyempurnakan yang sudah ada dan mengkreasikan hal baru yang lebih baik lagi, (4) Tanggung jawab, Bekerja secara tuntas dan konsekuen, serta (5)Keteladanan, menjadi contoh yang baik bagi orang lain.

Penerapan nilai lima budaya kerja ini termasuk pada karakteristik budaya organisasi yang dikemukakan oleh Robbins yang salah satunya ialah Inovasi. Pegawai yang professional tentunya selalu berusaha untuk berinovasi dan professional untuk mewujudkan etos kerja yang kuat, bermutu tinggi, dan memberikan kontribusi positif terhadap organisasinya. Pada pelaksanaan etos kerja di PAIS dapat diwujudkan melalui suatu jalinan dan kerjasama antar staff dan guru agama islam yang diawali dengan kegiatan pembinaan guru dan berkolaborasi dengan pihak-pihak terkait.

Melakukan pekerjaan dengan etos kerja sebagai budaya organisasi di PAIS tentu tidak bisa lepas dari hambatan atau kendala didalamnya. Pada dasarnya permasalahan yang sering terjadi dan mengganggu keberlangsungan pekerjaan di PAIS ialah 
masalah jaringan dan sistem eror. Tentunya hal ini mempengaruhi pekerjaan operator tidak bisa mengakses aplikasi untuk melakukan input data di EMIS, tetapi permasalahan ini memang seringkali terjadi dan bisa teratasi apabila sudah dikonsultasikan ke Kantor Wilayah atau pusat. Menghadapi permasalahan-permasalahan seperti ini meskipun sepele sebagai karyawan yang memiliki etos kerja tinggi harus menunjukkan budaya organisasi agresif, yaitu sejauh mana orang dalam organisasi tersebut agresif dan kompetitif bukan santai-santai ketika dalam pelaksanaan pekerjaan terdapat masalah.

Pegawai di PAIS yang bekerja dengan etos kerja tinggi tentu memberi keuntungan tersendiri bagi instansi. Beberapa manfaat etos kerja dalam mempengaruhi kualitas layanan di Wilayah Kantor Kementerian Agama Kabupaten Gresik ialah (1)Membuka semua jaringan dalam komunikasi, keterbukaan, kegotongroyongan, kekeluargaan, dan kebersamaan.(2)Adanya perubahan ke arah yang lebih baik, yang sifatnya pun fleksibel.(3)Menciptakan suasana kerja di PAIS nyaman karena memberikan tanggung jawabnya pada lingkungan pekerjaan.(4)Tugas terselesaikan sesuai waktu yang sudah ditetapkan.

\section{Kesimpulan}

Berdasarkan hasil penelitian, maka dapat disimpulkan Etos kerja dalam budaya organisasi di Wilayah Kantor Kementrian Agama Kabupaten Gresik pada proses di Seksi PAIS Beban tugas hanya dikerjakan oleh 2 (dua) pegawai dan juga selama beberapa bulan ini dipimpin oleh Pelaksana Tugas (PLT) tetapi semuanya bisa terselesaikan sesuai dengan target waktu yang sesuai dengan tujuan yang ditetapkan. ditandai dengan melakukan pekerjaan dengan sepenuh hati, menjauhi tindakan tercela. Tidak hanya itu Pada seksi pendidikan agama islam perilaku atau sikap yang harus diperhatikan supaya pegawai fokus pada peningkatan layanan ialah berpijak pada lima nilai budaya, yaitu Integritas, Profesionalitas, Inovasi, Tanggung jawab, dan Keteladanan.

Pekerjaan yang ada pada seksi ini dapat berlangsung sesuai dengan tujuan meskipun dipimpin oleh pelaksana tugas 
dikarenakan beberapa faktor pendukung lainnya, yakni pembagian tugas yang jelas di Seksi Pendidikan Agama Islam, pegawai bekerja dengan ikhlas dan sepenuh hati, memperhatikan dan mengutamakan kualitas layanan, terus belajar serta menjalin komunikasi yang baik antar pihak internal maupun eksternal. Faktor yang mempengaruhi etos kerja di PAIS diantaranya ialah adanya budaya organisasi. Budaya organisasi merupakan nilai, norma, aturan, falsafah, dan kepercayaan yang diyakini oleh sebuah organisasi yang tercermin dalam pola pikir dan perilaku para anggota organisasi. Dengan menerapkan etos kerja dalam budaya organisasi di PAIS keuntungan yang diperoleh instansi ialah (1)Membuka semua jaringan dalam komunikasi, keterbukaan,

kegotongroyongan, kekeluargaan, dan kebersamaan.(2)Adanya perubahan ke arah yang lebih baik, yang sifatnya pun fleksibel.(3)Menciptakan suasana kerja di PAIS nyaman karena memberikan tanggung jawabnya pada lingkungan pekerjaan.(4)Tugas terselesaikan sesuai waktu yang sudah ditetapkan.

Rekomendasi dari peneliti adalah supaya etos kerja perlu ditingkatkan lagi supaya dapat menjamin kualitas pelayanan terhadap guru agama islam di kabupaten Gresik dan juga kepada masyarakat. Selain itu, supaya tidak terjadi lagi sistem eror dan susah jaringan perlu adanya perbaikan sistem penanganan EMIS dan membuat jaringan yang dikhususkan untuk operator mengakses EMIS.

\section{References}

Amiruddin, Pengaruh Etos Kerja, Disiplin, dan Motivasi Terhadap Kinerja Pegawai pada Dinas Perindustrian dan Perdagangan Kabupaten Biak Numfor, (Pasuruan: Penerbit Qiara Media, 2019)

Arikunto, Suharsimi. 2010. Prosedur Penelitian : Suatu Pendekatan Praktik. Jakarta : Rineka Cipta. 
Ariwibowo, Onedy. 2020. Peran Budaya Organisasi. Semarang: Universitas Diponegoro.

Dewi, Iga Manuati. 2002. Makalah. Mengapa dan Untuk Apa Bekerja?. Bali: Universitas Udayana.

Fitriah. 2016. Budaya Organisasi. Makalah. Banjarmasin: Institut Agama Islam Negeri Antasari.

Gultom, Dedek Kurniawan., 2014. Pengaruh Budaya Organisasi Perusahaan Dan Motivasi terhadap Kinerja Karyawan Pada PT. Perusahaan Gas Negara (PERSERO) Tbk Medan. Jurnal Manajemen \& Bisnis Vol. 14 No. 02.

Hikmat.2011.“Manajemaen Pendidikan”, Bandung: Pustaka Setia.

Jansen Sinamo.2005. Manajemen Etos Kerja Profesional : Navigator Anda Menuju Sukses. Bogor: Institut Darma Mahardika

Kirana, Adiswara Muhammad. 2017. Pengaruh Kepemipinan dan Motivasi Kerja Terhadap Etos Kerja pada Departemen Warehouse PT. Mulia Boga Raya. Skripsi. Bekasi: Pelita Bangsa.

Moeheriono.2012. Pengukuran Kinerja Berbasis Kompetensi. Jakarta: PT. Rajagrafindo Persada.

Sari, Eliana. 2009. Budaya Organisasi Membangun Etos Kerja Profesional. Jakarta: Jayabaya Universitas Press.

Siswanto, dkk. 2019. The Influence of Islamic Work Ethic and Job Satisfaction on Organizational Commitment:Islamic Educational Institution Evidence. Jurnal Etikonomi, Vol 18 (1) Soetopo,Hendyat,. 2010. Perilaku Organisasi. Universitas Negeri Malang: Penerbit Remaja Rosda Karya

Sugiyono,2016, Cara Mudah Menyusun Skripsi, (Bandung : Penerbit Alfabeta,) Sugiyono. 2012. Metode Penelitian Kuantitatif Kualitatif dan H\&D . Bandung: Alfabeta Sutrisno ,Edy.2013. Manajemen Sumber Daya Manusia. Jakarta: Kencana

Toto Tasmara. 2002. Membudayakan Etos Kerja Islami.(Yogyakarta:

Gema Insani) 
Indah Nur Faizah, Linda Lisma Lestari, Syahrul Hidayat, Ali Mustofa

Vetriana, dkk. 2012. Pengaruh Kepemimpinan, Lingkungan Kerja dan Disiplin Kerja Terhadap Etos Kerja Karyawan Pada Bank Bengkulu Capem Wilayah Curup. Jurnal Ilmiah Manajemen, Vol 13 Nomor 2. 